\title{
Shelf-life of loricariid catfish (Pterygoplichthys disjunctivus [Weber, 1991]) roe stored in ice
}

\author{
Elva Janette GUILLÉN-SÁNCHEZ ${ }^{1}$, Ramón PACHECO-AGUILAR ${ }^{1}$, Susana María SCHEUREN-ACEVEDO ${ }^{1}$, \\ María Gisela CARVALLO-RUIZ1 ${ }^{1}$ Gerardo NAVARRO-GARCÍA², Juan Carlos RAMÍREZ-SUÁREZ¹ (D)
}

\begin{abstract}
Loricariid catfish (Pterygoplichthys disjunctivus [Weber, 1991]) has invaded water catchments throughout the world, due to the lack of predators and high fecundity. An approach to control its population could be using its roe as food; however, more knowledge is needed. Thus, the present study aimed to evaluate the shelf-life of fresh loricariid catfish roe stored in ice, as an approach for possible food utilisation. Physicochemical characteristics (moisture content, aw, $\mathrm{pH}$, hardness, and colour), protein electrophoresis (SDS-PAGE), amino and fatty acid contents, oxidative stability (TBARS) and microbiology of roe were analysed at $0,2,4,6,11,15$ and 21 days. Moisture content ( $58.5 \pm 2.1$ vs. $60.4 \pm 1.2 \%)$, aw (0.89) and $\mathrm{pH}(5.87 \pm 0.14$ vs. $5.96 \pm 0.03)$ were shelf-stable (initial vs. final day, respectively). SDS-PAGE showed minor hydrolysis of its protein. Ice storage increased roe free amino acid concentration, confirming proteolysis of its proteins/peptides with not impact on the fatty acid content and TBARS (2.4-3.3 mg malonadehyde/kg sample). Thus, ice storage of fresh loricariid catfish (P. disjunctivus [Weber, 1991]) roe, under the study conditions, proved to be an effective preservation method for its food utilisation, maintaining its physicochemical and microbiological characteristics for up to 20 days.
\end{abstract}

Keywords: Pterygoplichthys disjunctivus; Roe; shelf-life; ice storage.

Practical application: The ice storage of fresh loricariid catfish (P. disjunctivus [Weber, 1991]) roe showed to be an effective and economical preservation method, maintaining ideal physicochemical and microbiological characteristics for possible food utilisation. Besides, its use as food can benefit invaded locations since fishermen can obtain profitable benefits from its exploitation and, at the same time, it can prevent and help to the eventual elimination of the species in the water-invaded catchments.

\section{Introduction}

The loricariid catfish (Pterygoplichthys disjunctivus [Weber, 1991]) is an endemic species of the Madeira River Basin located in Bolivia and Brazil (Ferraris, 2007). This species has been commonly used around the world as an ornamental fish to clean fish tanks from algae and other debris. However, the species has made it to the wild and successfully invaded different water catchments throughout the world, for example, in Vietnam (Levin et al., 2008), the United States (Gibbs et al., 2008) and, more recently, South Africa (Hill et al., 2015). In Mexico, it has been found in reservoirs and rivers, causing ecological problems and affecting some local fisheries (Rueda-Jasso et al., 2013).

Its invasion success has been attributed to different reasons, such as alteration of bank structure and erosion (Nico et al., 2009), disruption of aquatic food chains (Capps et al., 2011), the presence of parental care and premature reproduction (Rueda-Jasso et al., 2013), and their resistance to certain salinity (Capps et al., 2011). However, the most influential characteristics for its success are that the females are highly prolific and iteroparous reproducers (Gibbs et al., 2013) combined with the lack of predators in the new invaded water catchments (Rueda-Jasso et al., 2013; Toro-Ramírez et al., 2014). However, although Toro-Ramírez et al. (2014) indicated that the common snook (Centropomus undecimalis [Bloch, 1792]) could be a predator (reported only in one location) of the species, the invasion has continued, and its population has grown.

In Mexico, the Adolfo López Mateos (El Infiernillo) Reservoir, located in the State of Michoacán, has been invaded by this species, affecting the economy of its surrounding communities, which depend on the Balsas catfish (Ictalurus balsanus), the redside cichlid (Cichlasoma istlanum) and tilapia fisheries (Mendoza et al., 2009), impacting them and also causing problems with the fishermen's nets. Currently, this species (abundant in the reservoir and its effluents) has been underutilised by the fishermen, who discard all of its catches, with subsequent adverse environmental impacts.

Recent research has shown the feasibility of using loricariid catfish muscle, either fresh (Marquez-Rios et al., 2016) or as a raw material for gel-type products (unpublished data) intended for human consumption. However, due to the relatively high total fecundity of the species, going from 2000 to 2500 eggs per left gonad (with a maximum capacity of 6,686 eggs) in the summer months (Rueda-Jasso et al., 2013), and its gonad proportion (representing around $30 \%$ of the fish weight). It is well recognized that fish roe is a nutritionally rich source, usually thrown away by the fish processors. In this regard, the loricariid catfish roe could also be used as a good source of nutrients since it possesses 
proteins with high essential amino acids and fatty acids with a good $\omega 6 / \omega 3$ balance (Guillén-Sánchez et al., 2015). However, to exploit the roe of this species as food, more research has to be conducted since there is practically no knowledge about it, neither its behaviour during its shelf-life. Consequently, it is important to elucidate its changes when managed and stored in ice. Thus, the objective of the present study was to evaluate the shelf-life of fresh loricariid catfish (P. disjunctivus [Weber, 1991]) roe stored in ice, as an approach for possible food utilisation.

\section{Materials and methods}

\subsection{Raw material}

Loricariid catfish (P. disjunctivus [Weber, 1991]) was obtained from the Marquez River, an important effluent of El Infiernillo Reservoir, by a local fisherman. The fish $(30.4 \pm 2.1$ length and $287.7 \pm 93.4$ weight, mean of both samplings, $\mathrm{n}=25$ ) was immediately stored in coolers in alternated layers of ice and fish, and transferred to the facilities of the Universidad de San Nicolas of Hidalgo in the State of Michoacán, Mexico, where they were eviscerated to obtain the gonads. Gonads were packed in two 1 -kg plastic containers, ice stored in a cooler and air-shipped to the Seafood Products Quality and Biochemistry Laboratory located in Hermosillo, Sonora, Mexico. The raw material was always processed within $24 \mathrm{~h}$ post-capture. Two samplings (May and July) were performed and undertaken under the same good sanitary conditions. For the study, $600 \mathrm{~g}$ of gonads were placed in Ziploc ${ }^{\circledR}$ freezer bags and stored between two layers of crushed ice in a cooler. Coolers were kept inside a $2{ }^{\circ} \mathrm{C}$ walk-in chiller for 21 days, with ice exchanged every 3 days. Sampling was conducted at days $0,2,4,6,11,15$ and 21 (or as stated otherwise). Figure 1 is representative of the loricariid catfish gonads and their eggs used in the present study.

\subsection{Physicochemical analysis of roe}

Roe was analysed for water content following the Association of Official Analytical Chemists (2000) (Method 950.46). Water activity $\left(a_{\mathrm{w}}\right)$ was measured with a PawKit hygrometer (Decagon Devices Inc., Pullman, WA, USA). pH was determined by direct immersion of electrode in the roe. Hardness of samples was evaluated with a TMS-PRO texturometer (Food Technology

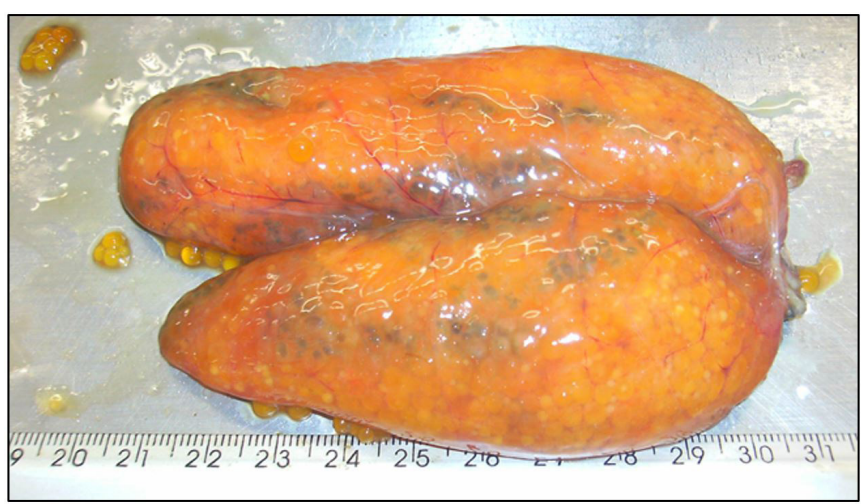

Figure 1. Loricariid catfish (P. disjunctivus [Weber, 1991]) gonads used in the present study. Numbers in rule are centimetres.
Corporation) equipped with a $100 \mathrm{~N}$ load cell, exerting a 50\% compression with a normal stress at $30 \mathrm{~mm}$ min-1 crosshead velocity. Sample (egg) was stabilized at the bottom of a support prepared specially for this purpose. Briefly, the support was made from a $1.5 \mathrm{~mL}$ microtube which was carefully cut at the conical section and then placed inside the rest of the cut tube (serving as a support for the conical section). Ten individual eggs were examined for each sample.

Besides, colour (lightness $\left[L^{\star}\right]$, chroma $\left[C^{\star}\right]$, hue angle $\left[h^{\circ}\right]$ ) parameters were measured using a Konica-Minolta CR-400 Tristimulus Colorimeter (Konica Minolta Sensing, Inc., Japan). Color coordinates were used to measure the degree of lightness $\left(L^{*}\right)$, redness-greenness $\left(+\right.$ or $\left.-a^{*}\right)$, and yellowness-blueness $\left(+\right.$ or $\left.-\mathrm{b}^{\star}\right)$. However, only lightness $\left[\mathrm{L}^{\star}\right]$ and additional color traits used for a better integration and interpretation of $\mathrm{a}^{\star}$ and $\mathrm{b}^{\star}$ values, such as hue angle $\left(h^{\circ}=\operatorname{Arctang}\left(\mathrm{b}^{\star} / \mathrm{a}^{\star}\right)\right.$ and chroma $\left(\mathrm{C}=\left(\mathrm{a}^{* 2} \times \mathrm{b}^{* 2}\right)^{1 / 2}\right)$ are discussed.

\subsection{Effect of storage on roe proteins}

Roe protein changes due to storage were analysed by sodium dodecyl sulphate-polyacrylamide gel electrophoresis (SDS-PAGE). Protein was obtained from the precipitate acquired from the Folch et al. (1957) methodology (see next section). Then, precipitate $(1 \mathrm{~g})$ was homogenized with $9 \mathrm{~mL}$ of dissolving solution ( $5 \%$ SDS, $0.1 \% \beta$-mercaptoethanol) using a Tekmar Tissumizer (Tekmar Co. W. Germany) for $1 \mathrm{~min}$ and then heated to $90{ }^{\circ} \mathrm{C}$ for $50 \mathrm{~min}$ to allow maximal protein solubilization and extraction. Subsequently, sample was filtrated with Whatman \#4. SDS-PAGE was performed accordingly to Laemmli (1970) with some modifications (constant current of 110 volts $)$. Discontinuous gels $(80 \times 60 \times 1.5 \mathrm{~mm}$, width $\times$ height $\times$ thickness) with separating and stacking gels of 13 and $4 \%$ acrylamide, respectively, were prepared. Filtrated solution was diluted ( $1: 1 \mathrm{v} / \mathrm{v}$ ratio) with sample buffer (4\% SDS, $20 \%$ glycerol, $10 \% \beta$-mercaptoethanol, $0.125 \mathrm{M}$ Tris, $\mathrm{pH} 6.8$ ) and dissolved by heating in boiling water for $3 \mathrm{~min}$. Aliquots of $15 \mu \mathrm{g}$ of protein per lane were loaded into the acrylamide gel. Proteins were stained for Coomassie brillant blue R-250 (Bio-Rad) and the molecular weights of protein bands were determine using a high molecular weight standard proteins kit (Bio-Rad).

\subsection{Effect of storage on roe fatty acid (FA) content}

Lipids were extracted from $6 \mathrm{~g}$ of samples (triplicates of different roe) according to the Folch methodology using chloroform:methanol $(2: 1 \mathrm{v} / \mathrm{v})$. Extracted lipids were flushed with nitrogen and frozen at $-80{ }^{\circ} \mathrm{C}$, until used for their fatty acid composition analysis. Fatty acids were derivatized to their correspondent methyl-esters using $14 \% \mathrm{BF}_{3}-\mathrm{MeOH}$ on $20 \mathrm{mg}$ of oil (in triplicate) (Morrison \& Smith, 1964). Briefly, lipid extract $(1 \mathrm{~mL})$ was evaporated in a water bath at $60^{\circ} \mathrm{C}$ under a constant nitrogen flux. Then, $20 \mathrm{mg}$ of oil were diluted with $1 \mathrm{~mL}$ of $0.5 \mathrm{M} \mathrm{NaOH}$ in methanol and $100 \mu \mathrm{L}$ of dichloromethane. Then, nitrogen was flushed and the tube was sealed and heated in a water bath at $90^{\circ} \mathrm{C}$ for $10 \mathrm{~min}$.

Finally, $1 \mathrm{~mL}$ of distilled water $+500 \mu \mathrm{L}$ of hexane $+500 \mu \mathrm{L}$ of internal standard (Tridecanoic acid, C13:0) (Sigma Aldrich, 
Bellafonte, USA) were added and slightly shaken. Identification and quantification of fatty acids methyl-esters (FAME) was obtained by capillary gas chromatography in a Agilent CG 6850, fitted with a capillary Agilent column DB-23 $(60 \mathrm{~m}, 0.25 \mathrm{~mm}$ id and $0.25 \mu \mathrm{m}$ film) and equipped with a split/split-less injector and a flame ionization detector temperature of $280^{\circ} \mathrm{C}$. A $35 \mathrm{~min}$ ramp was conducted as follows: Initial oven temperature was $50^{\circ} \mathrm{C}$; after $1 \mathrm{~min}$, temperature was raised to $175^{\circ} \mathrm{C}$ at $25^{\circ} \mathrm{C} / \mathrm{min}$; then temperature was raised to $230^{\circ} \mathrm{C}$ at $4^{\circ} \mathrm{C} / \mathrm{min}$ and sustained for $15 \mathrm{~min}$. Individual components were identified by comparing the retention times with those obtained from the FAME mixture standard (Supelco 37, Bellefonte, PA). Results were expressed as a percentage of the total fatty acid methyl esters present in the sample.

\subsection{Effect of storage on roe free amino acid (FAA) content}

Free amino acids determination in sample was carried out according to Pacheco-Aguilar et al. (1998) with a slight modification in buffer flux. Amino acid extraction was carried out by homogenizing $3 \mathrm{~g}$ of sample with $6 \mathrm{~mL}$ of $7.5 \%$ trichloroacetic acid (TCA) (ratio 1:2, roe: TCA) with an Ultra-turrax T25 Basic homogenizer for $2 \mathrm{~min}$ at $11,000 \mathrm{rpm}$ in an ice bath. The extract was centrifuged at $2830 \times \mathrm{g}$ for $15 \mathrm{~min}$ at $4{ }^{\circ} \mathrm{C}$ in a Beckman Centrifuge Model J2-21 and the supernatant was filtrated in Whatman \# 4 for analysis. Supernatant $(100 \mu \mathrm{L})$ was brought to $1 \mathrm{~mL}$ with $200 \mu \mathrm{L}$ internal standard $(10 \mu \mathrm{g} \mathrm{mL}-1, \mathrm{~L}-\alpha$-amine n-butiric acid) and $700 \mu \mathrm{L}$ HPLC water. A $400 \mu \mathrm{L}$ aliquot was taken and mixed with $400 \mu \mathrm{L}$ of O-Phthaldialdehyde (OPA, $10 \mathrm{mg}$ of $\mathrm{OPA}+250 \mu \mathrm{L}$ methanol $+37.5 \mu \mathrm{L}$ of Brij $35+25 \mu \mathrm{L}$ $\beta$-mercaptoethanol) and all were diluted to $10 \mathrm{~mL}$ with potassium borate buffer, $\mathrm{pH}$ 10.4. The mixture was filtered and derivatized for $2 \mathrm{~min}$ at room temperature and finally loaded into an HPLC using a $20 \mu \mathrm{L}$ loop. Amino acid concentration was quantified using a Series 1100 Hewlett Packard HPLC coupled with a fluorescence detector (350 nm excitation and $450 \mathrm{~nm}$ emission). Separation was conducted in a C18 octadecyl dimetilsilane reverse phase column $(3 \mu \mathrm{M}$ particle diameter, $100 \mathrm{~mm}$ long $\times 4.6 \mathrm{~mm} \mathrm{ID})$ (Variant Cat No. R0089200E3). A gradient elution consisting of buffer A (100\% methanol) and buffer B (10\% methanol, $90 \%$ acetate buffer, $\mathrm{pH}$ 6.5) was used for separation at a flow of $1.0 \mathrm{~mL}$ min-1. A 30 min run was conducted using an initial condition of mobile phase of $80 \%$ buffer B and $20 \%$ buffer A for 5 min; then a $70 \%$ buffer $B$ and $30 \%$ buffer A mobile phase was used for 5 min; next, $50 \%$ buffer B and $50 \%$ buffer A mobile phase was used for 5 min; subsequently, a $20 \%$ buffer B and $80 \%$ buffer A mobile phase was used for 7 min and finally an $80 \%$ buffer $B$ and $20 \%$ buffer A mobile phase was used for $8 \mathrm{~min}$. Data (area under the peaks produced by amino acid fluorescence) was analyzed by the CHEM STATION program (Agilent Technologies Inc. Santa Clara, CA, USA). Retention times and peak areas were compared with 16 amino acids standards (Sigma Chemical Co. St. Louis, MO, USA). Analysis was carried at days 0, 6, 11 and 21 of ice storage.

\subsection{Effect of storage on roe oxidative stability}

Thiobarbituric acid-reactive substances (TBARS) were quantified as a measure of oxidative stability throughout the shelf-life, using the colourimetric method described by Woyewoda et al. (1986). The results were expressed as $\mathrm{mg}$ of malonaldehyde/kg of sample.

\subsection{Microbiological analyses}

These analyses were carried out on $100 \mathrm{~g}$ of loricariid catfish roe at days $0,4,11$ and 21 of ice storage, according to the Food and Drug Administration (2011). Total plate count was evaluated for aerobic mesophilic and psychrophilic microorganisms (CFU/g), using plate count agar and incubation at $35 \pm 1^{\circ} \mathrm{C}$ for $48 \mathrm{~h}$, and at $5 \pm 2{ }^{\circ} \mathrm{C}$ for 7-10 days, respectively (Maturin \& Peeler, 1998). Potato dextrose agar was used to determine the yeast and moulds, and the plates were incubated at $25{ }^{\circ} \mathrm{C}$ for 4 days (Tournas et al., 1998). Total and faecal coliforms (MPN) were enumerated using tryptose lauryl sulphate broth at $35 \pm 2{ }^{\circ} \mathrm{C}$, and EC broth at $44.5 \pm 2{ }^{\circ} \mathrm{C}$, respectively (Feng et al., 1998). Assays were undertaken for detection of bacterial pathogens, including Staphylococcus aureus (on Baird Parker agar at $35^{\circ} \mathrm{C}$ for 48 h) (Bennet \& Lancette, 1998) and Salmonella spp. (on lactose broth at $35-37^{\circ} \mathrm{C}$ ) (Andrews \& Hammack, 1998).

\subsection{Statistical analysis}

Data were analysed as a randomised block design, using samplings $(n=2)$ as block criteria. Analysis of variance, and the multiple comparisons of means by the Tukey-Kramer multiple range test, were conducted at a significance level of $95 \%$, with the NCSS statistical package (Kaysville, UT, USA).

\section{Results and discussion}

\subsection{Effect of ice storage on the physicochemical characteristics of roe}

The physicochemical and structural characteristics of fish roe, which depend on the species and its physiology, determine its properties for its use as a raw matter or food. These properties are affected by storage and treatment (Stodołnik et al., 1992), which, in turn, can cause moisture loss, thereby reducing its stability. The moisture content of loricariid catfish roe showed a variable behaviour during ice storage, with a maximal value $(62.6 \pm 1.5 \%$, $\mathrm{p}<0.05)$ recorded on day 15 . However, comparable moisture contents were measured on the first and last sampling days (60.4 \pm 1.2 vs. $58.5 \pm 2.1 \%$, respectively, $\mathrm{p} \geq 0.05$ ). It is well known that the chemical composition of fish roe tend to be different due to intrinsic (species, roe maturity, egg location within the skein) as well as extrinsic (diet, fish maturity, season, harvest area and processing conditions) factors; besides, a fluctuation can be found even within the same female (Bledsoe et al., 2003; Katsiadaki et al., 1999). Differences found in the present study can be attributed to the diet and maturity conditions of the gonads. Overall, the results indicated no impact of ice storage on the moisture content of loricariid catfish roe; thus, maintaining the egg sheath integrity. This behaviour was similar to that found in echinoid (Paracentrotus lividus) marinated gonads (Stamatis \& Vafidis, 2009) and lumpfish roe (Cyclopterus lumpus) (Basby et al., 1998).

Conversely, one parameter that can affect the stability of a product is the $a_{\mathrm{w}}$. Loricariid catfish roe presented a stable $(\mathrm{p} \geq 0.05)$ $a_{\mathrm{w}}$ throughout the 21 days of ice storage, with an initial and final 
value of 0.89. Likewise, Hsu et al. (1983) recorded only small variations in an intermediate moisture mullet (Mugil cephalus) roe product, with an initial $0.84 a_{w}$, stored at $5^{\circ} \mathrm{C}$ for 30 days. On the other hand, the low $a_{\mathrm{w}}$ obtained in the present study contrasts with the fresh salmon roe values reported by Li et al. (2017), which were higher (0.96-0.98) than the ones obtained in the present study. This low value in the loricariid catfish roe is capable of holding the growing of certain microorganisms, helping to prolong its shelf life.

One important change that a product can suffer during its storage is its $\mathrm{pH}$, mainly due to microbial spoilage. In this regard, loricariid catfish roe did not show significant changes $(\mathrm{p} \geq 0.05)$ as storage progressed, presenting an initial $\mathrm{pH}$ of $5.87 \pm 0.14$, and a final $\mathrm{pH}$ of $5.96 \pm 0.03$; similar values were found on Alaska walleye pollock (Gadus chalcogrammus) roe (Anvari et al., 2018). This result indicates the roe pH stability during the ice storage; however, the slight increase towards the end of the study is indicative of microbial growth, as demonstrated below (see microbiology section).

There was a progressive decrease in the texture of loricariid catfish roe throughout storage (Figure 2), reaching a 31.3\% reduction $(\mathrm{p}<0.05)$ at the end of the study (from $25.6 \pm$ 8.1 [at day 0] to $17.6 \pm 7.3$ gf [at day 21]). Stodołnik et al. (1992) noticed the same trend in rainbow trout roe stored at $-25{ }^{\circ} \mathrm{C}$, attributing the changes in texture to lipolytic, as well as proteolytic enzymes. Besides, Kopylenko \& Rubtsova (2004), who studied salmon (Oncorhynchus gorbuscha) roe behaviour at different $\mathrm{pH}$, observed that proteolytic activity still occurred at $\mathrm{pH}$ around 6 (as seen in roe, in the present study). Thus, deterioration of loricariid catfish roe can also be attributed to the effect of proteolytic enzymes, as reflected in the SDS-PAGE analysis.

An important food attribute is its colour. Regarding this, loricariid catfish roe did not show significant $(\mathrm{P} \geq 0.05)$ changes in any of the parameters evaluated $\left(L^{*}, C^{*}, h^{\circ}\right)$ (Table 1$)$ throughout the shelf life. The $h^{\circ}$ values remained in the first quadrant (orange-yellow hues) of the colour sphere.

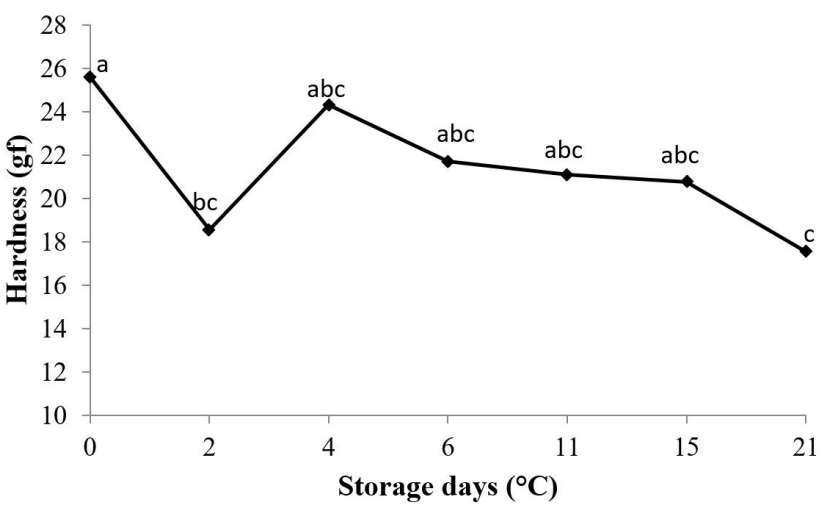

Figure 2. Changes in hardness (gf) of loricariid catfish (Pterygoplichthys disjunctivus) roe stored in ice $\left(0^{\circ} \mathrm{C}\right)$ for 21 days. ${ }^{\text {abc }}$ Different letters indicate significant differences $(\mathrm{P}<0.05)$ throughout storage. Data represent the mean of two repetitions $(n=2)$.

\subsection{Effect of ice storage over the electrophoretic profile of roe}

Loricariid catfish roe showed proteins of low (14 to $30 \mathrm{kDa}$ ), medium (45 to $70 \mathrm{kDa})$ and high $(77$ to $>200 \mathrm{kDa})$ molecular weight (MW), which underwent modifications during ice storage (Figure 3). Alterations in the electrophoretic pattern occurred from day 4; however, it was not until day 6 that a marked pattern of low MW bands appeared that was still apparent at the end of storage. The low-density bands with MW in the 6-21 and 25-45 kDa ranges most probably originated from the denser MW bands (at 14, 30, 77 and $360 \mathrm{kDa}$ ) since no visible variations were noted in these less-dense MW bands. Changes in the protein profile can result from the activity of the roe's endogenous proteases, as well as that of the exogenous proteases derived from microbial development, behaviour that can reduce its quality (Kopylenko \& Rubtsova, 2004).

\subsection{Effect of ice storage on the free amino acid (FAA) content of roe}

Rayner et al. (2017) related the significance of FAA concentration on fish eggs and their importance in the early growing stages of the fish for its optimal nutrition. On the sensorial side, the FAA's content in the roe can contribute to its flavour. In this regard, mayor FAA found in loricariid catfish roe were the essential amino acids lysine, leucine, valine, tyrosine, phenylalanine and isoleucine and the non-essential arginine, glutamic acid (umami), taurine, alanine and serine (both sweet). Alanine, leucine, serine, lysine, valine and isoleucine have been found as the majoritarian FAA in newly spawned eggs of 12 different fish species (Rayner et al., 2017), while glutamic acid has been related with "umami" and alanine and serine to sweet flavours (Jiang et al., 2016).

The FAA concentration in loricariid catfish roe stored in ice was affected $(\mathrm{P}<0.05)$, increasing as the storage progressed (Table 2). Overall, the total free amino acid content in roe increased $65 \%$ at day 11 , with a maximum of $4.44 \pm 0.1 \mathrm{mg} / \mathrm{g}$ of sample. These results confirm the action of proteolytic enzymes (as exhibited by SDS-PAGE) on the proteins/peptides found in roe during the ice storage, which promoted the release of amino acids. However, this proteolytic activity can produce both, an increase in the flavour of the roe (not affecting its nutritional quality) and, simultaneously, favour microbial growth in roe (Basby et al., 1998).

\subsection{Effect of ice storage on the fatty acid (FA) content of roe}

The dynamics of the FA composition of loricariid catfish roe stored in ice are reported in Table 3. In general, the FA remained stable during ice storage, with $27 \%$ to $30 \%$ monounsaturated FA, $22 \%$ to $28 \%$, polyunsaturated FA, and $44 \%$ to $49 \%$ saturated FA. Comprising around 25\%, $15-20 \%$ and $6-9 \%$ of the total FA in roe, the most abundant FA was palmitic acid (C16:0), followed by oleic acid $(\mathrm{C} 18: 1, \omega 9)$ and docosahexaenoic acid $(\mathrm{C} 22: 6, \omega 3)$, respectively $(\mathrm{p}<0.05)$. These FA were also the main constituents in tuna (Thunnus thynnus) roe (bottarga) stored at $4{ }^{\circ} \mathrm{C}$ (Restuccia et al., 2015), and in red salmon roe (Salmo trutta labrax) (Mol \& Turan, 2008). Among the monounsaturated FA, a considerable amount of palmitoleic 
Table 1. Effect of the ice storage $\left(0^{\circ} \mathrm{C}\right)$ over the colour parameters (lightness $L^{\star}$; chroma $C^{\star}$, hue angle $\left.h^{\circ}\right)$ of loricariid catfish $($ Pterygoplichthys disjunctivus) roe.

\begin{tabular}{cccccccc}
\hline \multirow{2}{*}{ Colour parameter } & \multicolumn{5}{c}{ Storage days $\left(0{ }^{\circ} \mathrm{C}\right)$} \\
\cline { 2 - 7 } & 0 & 2 & 4 & 6 & 11 & 15 & 21 \\
\hline$L^{*}$ & $35.7 \pm 3.6$ & $37.5 \pm 3.4$ & $37.2 \pm 2.6$ & $37.4 \pm 3.3$ & $39.6 \pm 5.8$ & $37.4 \pm 2.3$ & $37.3 \pm 2.6$ \\
$C^{*}$ & $32.0 \pm 4.4$ & $29.9 \pm 8.1$ & $30.7 \pm 3.7$ & $32.0 \pm 8.7$ & $35.1 \pm 11.1$ & $34.1 \pm 3.9$ & $32.0 \pm 6.7$ \\
$h^{\circ}$ & $68.9 \pm 7.0$ & $69.3 \pm 2.9$ & $66.4 \pm 2.3$ & $68.6 \pm 7.7$ & $70.6 \pm 4.4$ & $69.4 \pm 5.1$ & $66.6 \pm 7.9$ \\
\hline
\end{tabular}

Data are the mean \pm standard deviation of two replications $(n=2)$. No statistical changes were found in any parameter.

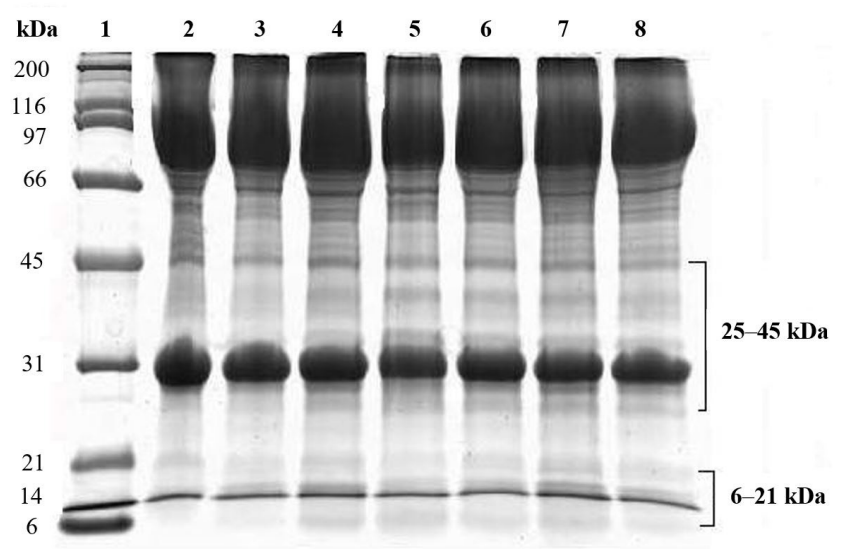

Figure 3. Effect of ice storage on the electrophoretic profile of loricariid catfish (Pterygoplichthys disjunctivus) roe. Molecular weight standard $(\mathrm{kDa})$ (row 1$)$. Ice storage $\left(0{ }^{\circ} \mathrm{C}\right)$ for $0,2,4,6,11,15$ and 21 days, indicated in rows $2-8$, respectively.

acid (C16:1) was evident, varying from 7 to $9 \%$ during the study, consistent with the FA contents reported in other freshwater fish roe, such as rohu (Labeo rohita), murrel (Channa striatus) (Prabhakara Rao et al., 2010) and, in the same order (Siluriformes), as the species examined in the current study, European catfish (Silurus glanis) (Saliu et al., 2017).

The $\omega 6 / \omega 3$ ratio, which can be related to health problems, such as atherosclerosis, obesity and diabetes, if unbalanced towards the $\omega 6$ FA, was kept under the "target region for health" of 1:1 ratio (or lower) (Simopoulos, 2011) throughout ice storage (Table 3 ). A similar FA composition was found by Guillén-Sánchez et al. (2015) on same species. The PUFA/SFA ratio showed lower values than those reported for European catfish (Silurus glanis); however, higher or equal to the minimum recommended value for human diet of 0.45 (Saliu et al., 2017).

\subsection{Effect of ice storage on the lipid oxidation stability of roe}

Lipid oxidation of loricariid catfish roe exhibited high stability throughout ice storage, with values $(\mathrm{p} \geq 0.05)$ ranging from 2.4 to $3.3 \mathrm{mg}$ malonaldehyde $/ \mathrm{kg}$ of sample (data not shown). No rancid odours were detected at any sampling time. However, odours, subjectively perceived as sweet and pleasant (fruity odours), were discerned at the end of the study, most probably due to the presence of aldehydes, like benzaldehyde, octanal and other aliphatic compounds (Caprino et al., 2008).
Table 2. Effect of ice storage $\left(0^{\circ} \mathrm{C}\right)$ on the free amino acids of loricariid catfish (Pterygoplichthys disjunctivus) roe.

\begin{tabular}{|c|c|c|c|c|}
\hline \multirow{2}{*}{ Amino acid } & \multicolumn{4}{|c|}{ Storage days $\left(0^{\circ} \mathrm{C}\right)$} \\
\hline & 0 & 6 & 11 & 21 \\
\hline Aspartic acid & 0.07 & 0.11 & 0.12 & 0.13 \\
\hline Glutamic acid & 0.25 & 0.30 & 0.33 & 0.32 \\
\hline Asparagine & 0.08 & 0.11 & 0.15 & 0.08 \\
\hline Serine & 0.11 & 0.17 & 0.20 & 0.21 \\
\hline Glutamine & 0.11 & 0.14 & 0.15 & 0.13 \\
\hline Glycine & 0.05 & 0.09 & 0.10 & 0.11 \\
\hline Tyrosine & 0.12 & 0.20 & 0.23 & 0.12 \\
\hline Taurine & 0.25 & 0.18 & 0.17 & 0.14 \\
\hline Alanine & 0.15 & 0.22 & 0.22 & 0.22 \\
\hline Histidine $^{*}$ & 0.08 & 0.17 & 0.22 & 0.22 \\
\hline Threonine $^{*}$ & 0.09 & 0.15 & 0.17 & 0.17 \\
\hline Arginine ${ }^{*}$ & 0.42 & 0.69 & 0.87 & 0.58 \\
\hline Methionine $^{*}$ & 0.10 & 0.21 & 0.19 & 0.20 \\
\hline Valine $^{*}$ & 0.13 & 0.24 & 0.25 & 0.25 \\
\hline Phenylalanine $^{*}$ & 0.12 & 0.24 & 0.22 & 0.20 \\
\hline Isoleucine $^{*}$ & 0.11 & 0.20 & 0.20 & 0.19 \\
\hline Leucine $^{*}$ & 0.21 & 0.30 & 0.28 & 0.27 \\
\hline Lysine $^{\star}$ & 0.28 & 0.42 & 0.42 & 0.54 \\
\hline EAA/NEAA & 0.80 & 0.58 & 0.59 & 0.56 \\
\hline Total & $2.68^{a}$ & $4.10^{\mathrm{b}}$ & $4.44^{\mathrm{b}}$ & $4.05^{b}$ \\
\hline
\end{tabular}

Data are presented as $\mathrm{mg} / \mathrm{g}$ of sample and represent the mean of two repetitions $(\mathrm{n}=2)$ with standard deviations of $<0.01^{\mathrm{a}, \mathrm{b}}$ Different superscripts are statistically different $(\mathrm{P}<0.05)$ ${ }^{\star}$ Essential amino acids Tryptophan and cysteine were not evaluated. EAA: essential amino acids; NEAA: non-essential amino acids

\subsection{Effect of ice storage on the microbiology of roe}

The microbiological growth (mesophiles, psychrophiles, yeasts and moulds) determined in loricariid catfish roe during ice storage is shown in Figure 4. Mesophilic bacteria presented an initial mean count of $4.48 \log _{10} \mathrm{CFU} / \mathrm{g}$, and decreased ( $\mathrm{p}<0.05)$ during the first 4 days of storage but, thereafter, started to increase up to the end of the study, reaching $5.57 \log _{10} \mathrm{CFU} / \mathrm{g}$ at day 21. Instead, psychrophilic bacteria can be an indicator of refrigerated product deterioration. In this study, the psychrophilic bacteria steadily increased $(\mathrm{p}<0.05)$ from 3.85 (at day 0) to $7.10 \log _{10} \mathrm{CFU} / \mathrm{g}$ of sample at day 21 , 
Table 3. Effect of ice storage $\left(0^{\circ} \mathrm{C}\right)$ on the fatty acids (\%) of loricariid catfish (Pterygoplichthys disjunctivus) roe.

\begin{tabular}{|c|c|c|c|c|c|c|c|}
\hline Fatty acid type & \multicolumn{7}{|c|}{ Storage days $\left(0^{\circ} \mathrm{C}\right)$} \\
\hline & \multicolumn{7}{|c|}{ Saturated fatty acids } \\
\hline C14:0 & $3 \pm 0.0$ & $4 \pm 0.0$ & $3 \pm 0.2$ & $3 \pm 0.1$ & $5 \pm 0.1$ & $4 \pm 0.1$ & $3 \pm 0.1$ \\
\hline C16:0 & $26 \pm 0.1$ & $26 \pm 0.1$ & $25 \pm 0.1$ & $27 \pm 0.1$ & $28 \pm 0.1$ & $25 \pm 0.1$ & $25 \pm 0.0$ \\
\hline $\mathrm{C} 22: 0$ & $1 \pm 0.0$ & --- & $1 \pm 0.0$ & $1 \pm 0.0$ & $1 \pm 0.1$ & $2 \pm 0.0$ & $2 \pm 0.0$ \\
\hline \multirow[t]{2}{*}{$\Sigma \mathrm{SFA}^{*}$} & 47 & 44 & 48 & 46 & 48 & 45 & 49 \\
\hline & \multicolumn{7}{|c|}{ Monounsaturated fatty acids } \\
\hline C14:1 & $2 \pm 0.0$ & $4 \pm 0.0$ & $3 \pm 0.0$ & $2 \pm 0.0$ & $6 \pm 0.0$ & $1 \pm 0.0$ & $1 \pm 0.0$ \\
\hline \multirow[t]{2}{*}{$\Sigma$ MUFA $^{*}$} & 29 & 28 & 27 & 27 & 30 & 30 & 29 \\
\hline & \multicolumn{7}{|c|}{ Polyunsaturated fatty acids } \\
\hline $\mathrm{C} 18: 2 \omega 6$, trans & $4 \pm 0.0$ & $5 \pm 0.0$ & $5 \pm 0.0$ & $4 \pm 0.0$ & $6 \pm 0.1$ & $5 \pm 0.0$ & $3 \pm 0.0$ \\
\hline $\mathrm{C} 18: 2 \omega 6$, cis & $1 \pm 0.0$ & $6 \pm 0.0$ & $5 \pm 0.0$ & $6 \pm 0.0$ & $2 \pm 0.1$ & $2 \pm 0.0$ & $2 \pm 0.0$ \\
\hline $\mathrm{C} 18: 3 \omega 3$ & $4 \pm 0.0$ & $5 \pm 0.0$ & $4 \pm 0.0$ & $5 \pm 0.0$ & $5 \pm 0.0$ & $5 \pm 0.0$ & $4 \pm 0.0$ \\
\hline C20:1 $\omega 9$ & $1 \pm 0.0$ & --- & $1 \pm 0.0$ & $2 \pm 0.0$ & $1 \pm 0.0$ & $1 \pm 0.0$ & $1 \pm 0.0$ \\
\hline C20:4 $\omega 6$ & $2 \pm 0.0$ & $2 \pm 0.0$ & --- & --- & $1 \pm 0.0$ & $2 \pm 0.0$ & $2 \pm 0.0$ \\
\hline $\mathrm{C} 20: 5 \omega 3$ & $2 \pm 0.0$ & $1 \pm 0.0$ & $2 \pm 0.0$ & $2 \pm 0.1$ & $1 \pm 0.0$ & $2 \pm 0.0$ & $2 \pm 0.0$ \\
\hline $\mathrm{C} 22: 6 \omega 3$ & $9 \pm 0.0$ & $9 \pm 0.0$ & $7 \pm 0.0$ & $8 \pm 0.1$ & $6 \pm 0.0$ & $9 \pm 0.0$ & $8 \pm 0.0$ \\
\hline
\end{tabular}

Data represent the mean \pm standard deviation of two repetitions $(\mathrm{n}=2) .{ }^{*}$ Different numbers in "total" rows by fatty acid type are statistically different $(\mathrm{P}<0.05)$. ---: Not found

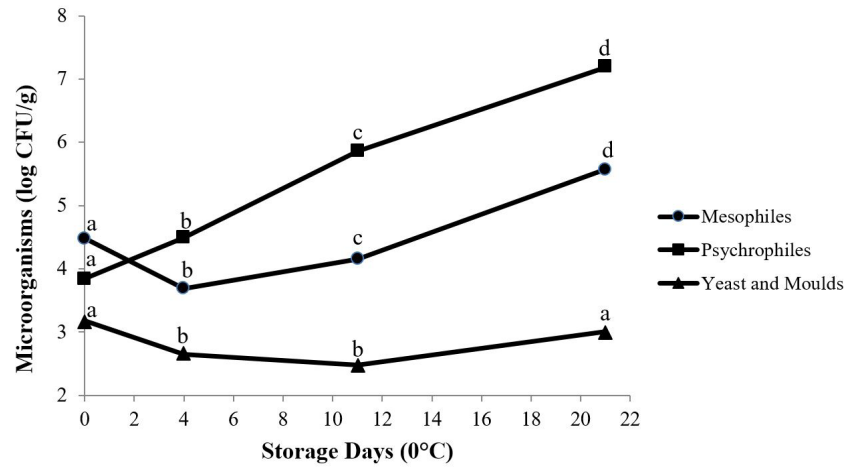

Figure 4. Microbiology (mesophiles, psychrophiles, yeasts and moulds) of loricariid catfish (Pterygoplichthys disjunctivus) roe stored in ice $\left(0^{\circ} \mathrm{C}\right)$. Data represent the mean of two repetitions $(n=2)$. a,b,c,d literals for each type of microorganism mean data is statistically different $(\mathrm{p}<0.05)$.

not unlike the counts measured in whiting (Gadus merlangus euxinus [Nordman, 1840]) roe by Kaba et al. (2013). It is important to mention that fish roe, due to its nature, can be prone to microbial development, especially yeast and moulds
(Mousavi et al., 2009). In this regard, fresh loricariid catfish roe presented low contamination by yeast and moulds (below $3.18 \log _{10} \mathrm{CFU} / \mathrm{g}$ ) throughout the study. Moreover, these types of microorganisms were affected by cold storage, as their counts slightly declined throughout the study. In comparison, Kaba et al. (2013) identified higher enumerations on whiting roe.

Based on the levels of pathogenic microorganisms evaluated, faecal coliforms (from 88 [at day 0] to $71 \mathrm{MPN} / \mathrm{g}$ [at day 21]), Salmonella spp. (absent in $25 \mathrm{~g}$ of sample, at all storage days) and $S$. aureus ( $-10 \mathrm{CFU} / \mathrm{g}$ at all storage days) were under the safe levels established by the (Food and Drug Administration, 2011). The low levels of total (180 MPN/g) and faecal coliforms suggest that the sanitary conditions used throughout the study were adequate. Microbial standards for caviar or fish roe have not yet been established. However, bacterial counts exceeding $7 \log _{10}$ $\mathrm{CFU} / \mathrm{g}$ are often taken as the limit for spoilage of fish products (International Commission on Microbiological Specifications for Foods, 1986; Rode \& Hovda, 2016). Thus, the present study showed that loricariid catfish roe stores at $0{ }^{\circ} \mathrm{C}$, following a hygienic handling practice, had a microbiological shelf-life of 
approximately 20 days, due to the increase in psychrophilic bacteria ( $>7 \log _{10} \mathrm{CFU} / \mathrm{g}$ ).

By nature, fish roe is designed to create and sustain life before hatching; in this way, it possesses a high nutritional value with an exceptional protein/amino acid profile combined with a high content of polyunsaturated fatty acids, among other components. Thus, although some protein hydrolysis occurred in the loricariid catfish roe and no major changes were observed in its lipids oxidation, overall results in the present study indicate that the species roe nutritional characteristics remained stable throughout the study (under the storage conditions used), making it an excellent option for its utilization as food.

\section{Conclusions}

Ice storage of fresh loricariid catfish ( $P$. disjunctivus [Weber, 1991]) roe, under the study conditions, proved to be an effective preservation method, maintaining ideal physicochemical and microbiological characteristics for possible food utilisation up to 20 days. The use of this roe as food can benefit invaded locations in several ways since fishers can obtain revenues from its exploitation and, at the same time, it can prevent and help contribute to the eventual elimination of $P$. disjunctivus invasion and presence in water catchments.

\section{Acknowledgements}

Authors wish to thank to Fondo Mixto CONACYT-Gobierno del Estado de Michoacán for the support to the project "Desarrollo Tecnológico para el Aprovechamiento e Industrialización del Pez Diablo en la Región del Bajo Balsas en Michoacán, FOMIX \# 37147" from which data was obtained for the realization of this manuscript.

\section{References}

Andrews, W. H., \& Hammack, T. S. (1998). Salmonella. In Food and Drug Administration. Bacteriological Analytical Manual. Gaithersburg, MD: AOAC International.

Anvari, M., Smith, B., Sannito, C., \& Fong, Q. (2018). Characterization of rheological and physicochemical properties of Alaska walleye pollock (Gadus chalcogrammus) roe. Journal of Food Science and Technology, 55(9), 3616-3624. http://dx.doi.org/10.1007/s13197018-3287-7. PMid:30150820.

Association of Official Analytical Chemists - AOAC. (2000). Method 950.46b Moisture content. Official Methods of Analysis (17th ed.). Gaithersburg, MD: AOAC International.

Basby, M., Jeppesen, V. F., \& Huss, H. H. (1998). Chemical Composition of Fresh and Salted Lumpfish (Cyclopterus lumpus) Roe. Journal of Aquatic Food Product Technology, 7(4), 7-21. http://dx.doi. org/10.1300/J030v07n04_03.

Bennet, R. W., \& Lancette, G. A. (1998). Staphylococcus aureus. In Food and Drug Administration. Bacteriological Analytical Manual. Gaithersburg, MD: AOAC Internationa.

Bledsoe, G. E., Bledsoe, C. D., \& Rasco, B. (2003). Caviars and fish roe products. Critical Reviews in Food Science and Nutrition, 43(3), 317-356. http://dx.doi.org/10.1080/10408690390826545. PMid:12822675.
Capps, K. A., Nico, L. G., Mendoza-Carranza, M., Arévalo-Frías, W., Ropicki, A. J., Heilpern, S. A., \& Rodiles-Hernández, R. (2011). Salinity tolerance of non-native suckermouth armoured catfish (Loricariidae: Pterygoplichthys) in south-eastern Mexico: implications for invasion and dispersal. Aquatic Conservation, 21(6), 528-540. http://dx.doi.org/10.1002/aqc.1210.

Caprino, F., Moretti, V. M., Bellagamba, F., Turchini, G. M., Busetto, M. L., Giani, I., Paleari, M. A., \& Pazzaglia, M. (2008). Fatty acid composition and volatile compounds of caviar from farmed white sturgeon (Acipenser transmontanus). Analytica Chimica Acta, 617(1-2), 139-147. http://dx.doi.org/10.1016/j.aca.2008.02.005. PMid:18486649.

Feng, P., Weagant, S. D., \& Grant, M. A. (1998). Enumeration of Escherichia coli and the Coliform Bacteria. In Food and Drug Administration. Bacteriological Analytical Manual. Gaithersburg, MD: AOAC International.

Ferraris, J. C. J. (2007). Checklist of catfishes, recent and fossil (Osteichthyes: Siluriformes), and catalogue of siluriform primary types. Zootaxa, 1418(1), 1-628. http://dx.doi.org/10.11646/zootaxa.1418.1.1.

Folch, J., Lees, M., \& Sloane Stanley, G. H. (1957). A simple method for the isolation andpurification of total lipides from animal tissues. The Journal of Biological Chemistry, 226(1), 497-509. PMid:13428781.

Food and Drug Administration - FDA. (2011). Fish and fishery products hazards and controls guidance (4th ed.). FDA: Silver Spring, MD.

Gibbs, M. A., Kurth, B. N., \& Bridges, C. D. (2013). Age and growth of the loricariid catfish Pterygoplichthys disjunctivus in Volusia Blue Spring, Florida. Aquatic Invasions, 8(2), 207-218. http://dx.doi. org/10.3391/ai.2013.8.2.08.

Gibbs, M. A., Shields, J. H., Lock, D. W., Talmadge, K. M., \& Farrell, T. M. (2008). Reproduction in an invasive exotic catfish Pterygoplichthys disjunctivus in Volusia Blue Spring, Florida, U.S.A. Journal of Fish Biology, 73(7), 1562-1572. http://dx.doi.org/10.1111/j.10958649.2008.02031.x.

Guillén-Sánchez, E. J., Pacheco-Aguilar, R., Lugo-Sánchez, M. E., Scheuren-Acevedo, S. M., Carvallo-Ruiz, M. G., Navarro-García, G., \& Ramirez-Suarez, J. C. (2015). Partial Characterization of loricariid catfish (Pterygoplichthys disjunctivus, WEBER, 1991) roe. Biotecnia, 17(3), 15-21. http://dx.doi.org/10.18633/bt.v17i3.214.

Hill, J. M., Jones, R. W., Hill, M. P., \& Weyl, O. L. F. (2015). Comparisons of isotopic niche widths of some invasive and indigenous fauna in a South African river. Freshwater Biology, 60(5), 893-902. http:// dx.doi.org/10.1111/fwb.12542.

Hsu, H. W., Deng, J. C., Koburger, J. A., \& Cornell, J. A. (1983). Storage Stability of Intermediate Moisture Mullet Roe. Journal of Food Science, 48(1), 172-175. http://dx.doi.org/10.1111/j.1365-2621.1983.tb14816.x.

International Commission on Microbiological Specifications for Foods - ICMSF. (1986). Microorganisms in foods 2: Sampling for microbiological analysis: Principles and specific applications. Toronto: University of Toronto Press.

Jiang, W. D., Wu, P., Tang, R. J., Liu, Y., Kuang, S. Y., Jiang, J., Tang, L., Tang, W. N., Zhang, Y. A., Zhou, X. Q., \& Feng, L. (2016). Nutritive values, flavor amino acids, healthcare fatty acids and flesh quality improved by manganese referring to up-regulating the antioxidant capacity and signaling molecules TOR and Nrf2 in the muscle of fish. Food Research International, 89(Pt 1), 670-678. http://dx.doi. org/10.1016/j.foodres.2016.09.020. PMid:28460965.

Kaba, N., Çorapc1, B., Eryaşar, K., \& Karabek, H. N. (2013). Sensory, chemical and microbiological characteristics of canned-smoked whiting roe pate. Gida, 38, 259-266. http://dx.doi.org/10.5505/ gida.2013.35229. 
Katsiadaki, I. G., Taylor, K. D. A., \& Smith, G. (1999). Assessment of quality of cod roes and relationship between quality and maturity stage. Journal of the Science of Food and Agriculture, 79(10), 1249-1259. http:// dx.doi.org/10.1002/(SICI)1097-0010(19990715)79:10<1249::AIDJSFA356>3.0.CO;2-J.

Kopylenko, L. R., \& Rubtsova, T. E. (2004). Effect of Pasteurization on the Activity of Proteinases in Salmon Roe. Applied Biochemistry and Microbiology, 40(5), 441-444. http://dx.doi.org/10.1023/ B:ABIM.0000040664.96905.d9. PMid:15553780.

Laemmli, U. K. (1970). Cleavage of structural proteins during the assembly of the head of bacteriophage T4. Nature, 227(5259), 680685. http://dx.doi.org/10.1038/227680a0. PMid:5432063.

Levin, B. A., Phuong, P. H., \& Pavlov, D. S. (2008). Discovery of the Amazon sailfin catfish Pterygoplichthys pardalis (Castelnau, 1855) (Teleostei: Loricariidae) in Vietnam. Journal of Applied Ichthyology, 24(6), 715-717. http://dx.doi.org/10.1111/j.1439-0426.2008.01185.x.

Li, C., Huang, L., \& Hwang, C. A. (2017). Effect of temperature and salt on thermal inactivation of Listeria monocytogenes in salmon roe. Food Control, 73, 406-410. http://dx.doi.org/10.1016/j. foodcont.2016.08.027.

Marquez-Rios, E., Pacheco-Aguilar, R., Ramirez-Suarez, J. C., OcanoHiguera, V. M., García-Sifuentes, C. O., Scheuren-Acevedo, S. M., \& Mazorra-Manzano, M. A. (2016). Postmortem biochemical and microbiological changes in loricariid catfish (Pterygoplichthys disjunctivus) muscle during ice storage. Journal of Aquatic Food Product Technology, 25(1), 105-113. http://dx.doi.org/10.1080/10 498850.2013.828146.

Maturin, L. J., \& Peeler, J. T. (1998). Aerobic plate count. In Food and Drug Administration. Bacteriological Analytical Manual. Gaithersburg, MD: AOAC International.

Mendoza, A. R., Escalera, G. C., Contreras, B. S., Koleff, O. P., Ramírez, M. C., Álvarez, T. P., Arroyo, D. M., \& Orbe, M. A. (2009). Invasión de plecos en la presa El Infiernillo, México: análisis de efectos socioeconómicos (relato de dos invasores). In R. E. Mendoza Alfaro, B. Cudmore, R. Orr, J. P. Fisher, S. Contreras Balderas, W. R. Courtenay, P. Koleff Osorio, N. Mandrak, P. Álvarez Torres, M. Arroyo Damián, C. Escalera Gallardo, A. Guevara Sanginés, G. Greene, D. Lee, A. Orbe Mendoza, C. Ramírez Martínez \& O. Stabridis Arana (Eds.), Directrices trinacionales para la evaluación de riesgos de las especies acuáticas exóticas invasoras, (pp. 42-51. Comisión para la Cooperación Ambiental, Montreal (Quebec), Canadá

Mol, S., \& Turan, S. (2008). Comparison of proximate, fatty acid and amino acid compositions of various types of fish roes. International Journal of Food Properties, 11(3), 669-677. http:// dx.doi.org/10.1080/10942910701611170.

Morrison, W. R., \& Smith, L. M. (1964). Preparation of fatty acid methyl esters and dimethyl acetals from lipids with boron fluoride-methanol. Journal of Lipid Research, 5, 600-608. PMid:14221106.

Mousavi, S. M., Mirzargar, S. S., Mousavi, H. E. Z., Baigi, R. O., Khosravi, A., Bahonar, A., \& Ahmadi, M. R. (2009). Evaluation of antifungal activity of new combined essential oils in comparison with malachite green on hatching rate in rainbow trout (Oncorhynchus mykiss) eggs. Su Ürünleri Dergisi, 4, 103-110. http://dx.doi.org/10.3923/ jfas.2009.103.110.

Nico, L. G., Jelks, H. L., \& Tuten, T. (2009). Non-native suckermouth armored catfishes in Florida: Description of nest burrows and burrow colonies with assessment of shoreline conditions. Aquatic Nuisance Species Research Program ANSRP Bull., 9(1), 1-30.
Pacheco-Aguilar, R., Lugo-Sánchez, M. E., Villegas-Ozuna, R. E., \& Robles-Burgueno, R. (1998). Histamine quantification in Monterey sardine muscle and canned products from northwestern Mexico. Journal of Food Composition and Analysis, 11(2), 188-195. http:// dx.doi.org/10.1006/jfca.1998.0574.

Prabhakara Rao, P. G., Jyothirmayi, T., Karuna, M. S. L., \& Prasad, R. B. N. (2010). Studies on lipid profiles and fatty acid composition of roe from rohu (Labeo rohita) and murrel (Channa striatus). Journal of Oleo Science, 59(10), 515-519. http://dx.doi.org/10.5650/ jos.59.515. PMid:20877143.

Rayner, T. A., Hwang, J. S., \& Hansen, B. W. (2017). Anticipating the free amino acid concentrations in newly hatched pelagic fish larvae based on recently fertilized eggs and temperature. Journal of Plankton Research, 39(6), 1012-1019. http://dx.doi.org/10.1093/plankt/fbx058.

Restuccia, D., Spizzirri, U. G., Bonesi, M., Tundis, R., Menichini, F., Picci, N., \& Loizzo, M. R. (2015). Evaluation of fatty acids and biogenic amines profiles in mullet and tuna roe during six months of storage at $4^{\circ} \mathrm{C}$. Journal of Food Composition and Analysis, 40, 52-60. http:// dx.doi.org/10.1016/j.jfca.2014.12.014.

Rode, T. M., \& Hovda, M. B. (2016). High pressure processing extend the shelf life of fresh salmon, cod and mackerel. Food Control, 70, 242-248. http://dx.doi.org/10.1016/j.foodcont.2016.05.045.

Rueda-Jasso, R. A., Campos-Mendoza, A., Arreguín-Sánchez, F., DíazPardo, E., \& Martínez-Palacios, C. A. (2013). The biological and reproductive parameters of the invasive armored catfish Pterygoplichthys disjunctivus from Adolfo López Mateos El Infiernillo Reservoir, Michoacán-Guerrero, Mexico. Revista Mexicana de Biodiversidad, 84(1), 318-326. http://dx.doi.org/10.7550/rmb.26091.

Saliu, F., Leoni, B., \& Della Pergola, R. (2017). Lipid classes and fatty acids composition of the roe of wild Silurus glanis from subalpine freshwater. Food Chemistry, 232, 163-168. http://dx.doi.org/10.1016/j. foodchem.2017.04.009. PMid:28490059.

Simopoulos, A. P. (2011). Evolutionary aspects of diet: The Omega-6/ Omega-3 Ratio and the Brain. Molecular Neurobiology, 44(2), 203215. http://dx.doi.org/10.1007/s12035-010-8162-0. PMid:21279554.

Stamatis, N., \& Vafidis, D. (2009). Effect of marinating and vacuum storage at $6^{\circ} \mathrm{C}$ on the fate of chemical, microbial and sensory quality indices of echinoid gonads Paracentrotus lividus Lamark, 1816. International Journal of Food Science \& Technology, 44(8), 1626-1633. http://dx.doi.org/10.1111/j.1365-2621.2009.01940.x.

Stodołnik, L., Salacki, M., \& Rogozińska, E. (1992). Changes in sheath properties of rainbow trout eggs during cold and frozen storage. International Journal of Refrigeration, 15(5), 270-275. http://dx.doi. org/10.1016/0140-7007(92)90041-R.

Toro-Ramírez, A., Wakida-Kusunoki, A. T., Amador-del Ángel, L. E., \& Cruz-Sánchez, J. L. (2014). Common snook [Centropomus undecimalis (Bloch, 1792)] preys on the invasive Amazon sailfin catfish [Pterygoplichthys pardalis (Castelnau, 1855)] in the Palizada River, Campeche, southeastern Mexico. Journal of Applied Ichthyology, 30(3), 532-534. http://dx.doi.org/10.1111/jai.12391.

Tournas, V., Stack, M. E., Mislivec, P. B., Koch, H. A., \& Bandler, R. (1998). Yeasts, Molds and Mycotoxins. In Food and Drug Administration. Bacteriological Analytical Manual. Gaithersburg, MD: AOAC International..

Woyewoda, A. D., Shaw, S. J., Ke, P. J., \& Burns, B. G. (1986). Recommended laboratory methods for assessment of fish quality. Halifax, Nova Scotia: Department of Fisheries and Oceans. 